\title{
Selecting an English Coursebook: Theory and Practice
}

\author{
Iakovos Tsiplakides \\ English teacher in secondary education, Greece \\ Email: tsiplakides@ hotmail.com
}

\begin{abstract}
Research on coursebook selection and evaluation suggests that the process of selecting an English coursebook is a complex and multifaceted task. Especially at a time when the market is inundated with a host of coursebooks for the teaching of English as a second or foreign language, selecting a suitable coursebook becomes a critical process, since it can have an enormous impact on students' engagement, motivation to learn, and ultimately their language performance. In this article we present the theoretical background on coursebook selection. We first discuss the role of the coursebook in English language instruction, and a short literature review on the advantages and disadvantages of using it. We also describe the two main types of coursebook evaluation, predictive and retrospective evaluation. The next part deals with the critical issue of adapting English coursebooks, so that they cater for the specific students' needs and match the purposes of the curriculum. We finally deal with the pedagogical implications, offering practical advice and suggestions about how teachers might become more successful in selecting a coursebook in the teaching of English as a second or foreign language.
\end{abstract}

Index Terms - coursebook, teaching of English as a second or foreign language

\section{INTRODUCTION}

A common element in the teaching of English as a second or foreign language is the coursebook. Indeed, it has been argued that the coursebook is an almost universal element of ELT teaching (Hutchinson and Torres, 1994). However, at a time when "the ELT market is inundated with state-of-the-art coursebooks teaching modern-day English" (Illes, 2009, p. 145), English teachers often have a difficult time selecting an appropriate coursebook that will suit the needs of their students and is in accordance with the curriculum. Researchers have supported the view that "the selection of a coursebook signals an executive educational decision in which there is considerable professional, financial and even political investment" (Sheldon, 1988, p. 237).

Bearing this in mind, the aim of this paper is to provide a synthesis of theory and practice and present an effective implementation of the process of coursebook selection in the teaching of English as a second or foreign language. Although a lot of research has been conducted on the theoretical principles underlying coursebook design, evaluation and selection, it remains a challenge to select and appropriate English coursebook. Thus, our purpose is to fill this research gap between theory and practice, and in doing so to provide teachers with an array of easy to follow suggestions and strategies which they can use in the coursebook selection process, after taking into account their unique teaching situation and their students' needs.

\section{WHY DO WE NEED COURSEBOOKS?}

It is widely accepted that the coursebook lies at the heart of any English language teaching situation (Sheldon, 1988; Hutchinson and Torres, 1994). They offer advantages for teachers and language students alike, and they constitute a useful resource for both teachers and learners (Richards, 1993). They are a convenient basis "on which to mould the unpredictable interaction which is necessary to classroom language learning" (O'Neill 1982, p. 104). According to Sheldon (1988) the following reasons justify the widespread use of coursebooks in the teaching of English as a foreign or second language throughout the world. Firstly, coursebooks are indispensable in ELT contexts because it is difficult for teachers themselves to create their own teaching material. In addition, coursebooks lessen preparation time by providing ready-made teaching texts and learning tasks and. Finally, coursebooks can serve both as a syllabus and as a framework of classroom progress, a measure by which teaching can be evaluated by external stakeholders. Coursebooks usually serve multiple roles in ELT, such as (Cunningsworth, 1995):

a) a resource for presentation material (spoken/written)

b) a source of activities for learner practice and communicative interaction.

c) a reference source

d) a syllabus

e) a resource for self-directed learning or self-access work.

f) a support for less experienced teachers. 


\section{AdVANTAGES AND DisADVANTAGES OF COURSEBOOKS}

A growing body of research examines the advantages of using a coursebook. In the relevant literature the following positive outcomes of the effective exploitation of coursebooks in the English classroom are mentioned:

a) Coursebooks are psychologically indispensable for students since their progress and achievement can be measured concretely when they are used in the English classroom (Haycroft, 1998)

b) Published materials have more credibility for students than teacher-generated or "in-house" materials (Sheldon, 1988)

c) Coursebooks are usually sensitive to students' needs, even if they are not written specifically for them, they save time and money, and they can and should allow for adaptation and improvisation to suit the requirements of a given teaching situation (O'Neill, 1982)

d) Coursebooks are relatively inexpensive and need little preparation time for lesson planning, whereas teacherenerated materials can be defective in terms of time, cost and quality. They also reduce the danger of teacher occupational overload (Sheldon, 1988)

e) Coursebooks constitute an effective resource for self-directed learning and for presentation of material, a source of ideas and activities, a reference source for students, a syllabus where they reflect pre-determined learning objectives, and support for less experienced teachers who may be lacking in confidence (Cunningsworth, 1995).

Apart from the above benefits, coursebooks provide structure and a syllabus for a program, they help standardize instruction, maintain quality, provide a variety of learning resources, are efficient because they save teachers' time, can provide effective language models and input, and are usually visually appealing and attractive for students. Furthermore, they can provide the initial framework which can be adapted by teachers to suit the needs and learning style of students (Cunningsworth, 1984). Empirical research in ELT settings has provided strong evidence that coursebooks can provide practice activities, a structured language program for teachers to follow, present language models, and information about the language (Richards, Tung, and $\mathrm{Ng}, 1992$ ).

Finally, Harmer argues that "where a textbook is involved there are obvious advantages for both teacher and students. Good textbooks often contain lively and interesting material; they provide a sensible progression of language items, clearly showing what has to be learnt and in some cases summarizing what has been studied so that students can revise grammatical and functional points that they have been concentrating on. Textbooks can be systematic about the amount of vocabulary presented to the student and allow students to study on their own outside the class. Good textbooks also relieve the teacher from the pressure of "having to think of original material for every class" (Harmer, 1991, p. 257).

Despite the above undeniable benefits of coursebooks, however, coursebooks have also been criticized for the following reasons.

a) Coursebooks are not flexible and generally simply mirror the pedagogic, psychological, and linguistic preferences and biases of their authors

b) Coursebooks contain social and cultural biases, such as gender bias, sexism, and stereotyping (Carrell and Korwitz, 1994; Renner, 1997)

c) They are often too contrived and artificial in their presentation of the target language. For example many scripted language models and dialogues are unnatural and inappropriate for communicative or cooperative language teaching

d) Textbooks may prevent teachers' creativity if teachers are obliged to follow the coursebooks sequence to the letter (Skierso, 1991, p. 432)

e) The teacher's role is undermined. Teachers may find themselves as mediators; they only carry out teaching practices imposed on them (Ur, 1991).

Among the main negative effects of the use of coursebooks is that they may contain inauthentic language, may distort content, they may not satisfy students' needs and they may be expensive to buy.

Summarising the above research findings, it should be noted that both the benefits and limitations of the use of coursebooks need to be considered in the critical process of coursebook selection for the teaching of English as a second or foreign language. If the coursebooks that are being used in a program are judged to have some negative consequences (e.g. the do not stimulate the students; interest, and/or they contain a few authentic reading texts), remedial action should be taken, e.g. by adapting or supplementing books or by providing appropriate guidance and support for teachers in how to use them appropriately.

\section{Types of COURSEBoOK Evaluation: PREDICTIVE AND RETROSPECTIVE EVALUATION}

As has already been stated, one of the most challenging tasks English teachers are often faced with if that of choosing a coursebook suitable for their teaching situation. They have to select a coursebook that suits the needs of their students, their unique characteristics and their preferences and one that the teacher believe will motivate them. The ultimate purpose, of course, is to choose a coursebook that will help the students increase their language performance. However, choosing a coursebook is a demanding task, because "it is clear that coursebook assessment is fundamentally a subjective, rule-of-thumb activity, and that no neat formula, grid or system will ever provide a definite yardstick" (Sheldon, 1988, p. 245). Selecting a suitable coursebook is not a straightforward process, as "selecting a suitable coursebook is not a simple task" (Chambers, 1997, p. 29). In the process of evaluating teaching material there are some 
pedagogical factors to be considered such as "suitability for the age group, cultural appropriateness, methodology, level quality, number and type of exercises, skills, teacher's book, variety, pace, personal involvement, and problem solving" (Chambers, 1997, p. 29-30).

A brief review of the literature on materials evaluation reveals that most researchers distinguish between two types of materials evaluation: a) predictive evaluation, and b) retrospective evaluation (Cunningsworth, 1995; Ellis, 1997). The basic principles and theoretical assumptions of each type are presented below.

\section{A. Predictive Evaluation}

Predictive evaluation refers to evaluation with the aim of deciding what materials to use. Teachers first take into consideration the materials available to them, and then they determine which are "best suited to their purposes" (Ellis, 1997, p. 36). There are two main ways through which teachers can conduct this kind of evaluation. First, they can depend on evaluations and assessment of teaching materials and coursebook conducted by experienced researchers and educators. For example, they can rely on evaluations published in scientific journals, in which the reviewers describe the criteria they have used, and their general philosophy for evaluation. Second, teachers may decide that it is best for them not to rely on other people's evaluations (no matter how experienced they may be), but instead, they may wish to carry out their own evaluation. It is also possible that teachers can use both types of predictive evaluation. If they want to conduct their own evaluation, they will need to read and consult books and articles dealing with materials evaluation, which provide a set of criteria for evaluating teaching materials. For example, a number of researchers provide checklists and sets of relevant criteria that help teachers in the evaluating process (Cunningsworth 1984; Skierso, 1991; McDonough and Shaw, 1993). The underpinning philosophy is that such sets of criteria assist teachers conduct a predictive evaluation in a systematic way. For example, For example, Cunningsworth (1995) proposes the following criteria for the evaluation of coursebooks:

a) Coursebooks should correspond to learner's needs. They should match the aims and objectives of the languagelearning program.

b) Coursebooks should reflect the uses (present or future) learners will make of the language. Textbooks should be chosen that will help students use language effectively for their own purposes.

d) Coursebooks should take account of students' needs as learners and should facilitate their learning processes, without dogmatically imposing a 'rigid' method.

d) Coursebooks should have a clear role as a support for learning.

\section{B. Retrospective Evaluation}

The term retrospective evaluation refers to evaluation designed to examine materials that have actually been used. The teacher does not carry out an evaluation with the ultimate aim of predicting whether a given coursebook is suitable for his/her teaching situation. Instead, the teacher makes a decision as to a coursebook s/he has used was worth using, if, in other words, was in accordance with the learners' needs, if the tasks and activities included in it motivated them, and helped them improve their language performance. In this way the teacher decides whether a specific coursebook is worth using again, or if a new one has to be used. There are two main ways through which retrospective evaluation can be conducted. The first, and the most commonly used way of conducting retrospective evaluation, is to engage in what is known as "impressionistic evaluation". This involves teachers' assessing, during the language course, which activities and materials were actually beneficial, so that at the end of the course they can make a summative judgement of the materials they have used (Ellis, 1997). The second way to carry out retrospective evaluation is to try to collect information in a more systematic manner, and conduct an empirical evaluation. This usually involves a "microevaluation", which requires an overall assessment of whether an entire set of materials has proved to be beneficial and suitable in a given teaching situation. Most commonly a micro-evaluation of teaching materials is carried out in relation to a task, defined as an activity in which meaning is of primary importance, there is a correlation to real-life situations, and the evaluation of how well students performed in the task is carried out on the basis of the outcome of the task (Skehan, 1998). The evaluation of a given task involves the following steps (Ellis, 1997):

Step 1: Choosing a task to evaluate

Step 2: Describing the task

Step 3: Planning the evaluation

Step 4: Collecting the information for the evaluation

Step 5: Analysing the information

Step 6: Reaching conclusions and making recommendations

Step 7: Writing the report

\section{Evaluating TASKS IN COURSEBOOKS}

When we evaluate the quality of reading tasks and activities included in an English coursebook, four questions are important:

a) Do the reading tasks contribute to the learners' language acquisition and development of reading skills? Some activities included in textbooks are convenient for teachers (e.g. multiple choice activities which have one "correct" 
answer), but they do not necessarily contribute to the learners' reading development. Coursebooks should include reading tasks that offer students opportunities to practice their reading skills. For instance, activities that require students to draw inferences, read between the lines, attend to writer bias, may support the development of reading skills and help students negotiate for meaning in real-life situations.

b) Are the activities balanced in format, containing both free and controlled practice? Multiple choice tasks, or fillin-the-blank activities guide students to a single correct answer. Free practice involves open-ended activities (such as writing or speaking in the post-reading stage, making a prediction in the pre-reading stage or confirming predictions in the while-reading stage) which offer students an opportunity to read with a real-life purpose (e.g. to read in order to confirm or reject a prediction).

c) Do activities progress in such a way that they capitalize on what students have already learned? Activities should progress from simple to more complex, both linguistically and cognitively. Coursebooks should require more from students as their language skills develop to keep them interested and challenged.

d) Are the activities challenging and varied in format? Routine can make students lose interest and lead to boredom. Tasks and texts should serve as a stimulus for communication and lead to stimulating writing or speaking tasks. For example, many coursebooks rely too heavily on comprehension questions, depriving students of an opportunity to read a text with a real-life purpose. Coursebooks need to include reading activities that demand students to make use of a wide range of cognitive skills so as to be challenging to students.

\section{ADAPTING ENGLISH COURSEBOOKS}

An essential skill for teachers is to be able to adapt the coursebooks they use in their classrooms so as to cater for their students' level of language development, and to address weaknesses of the coursebooks. Through the process of adaptation the teacher a) personalizes the text making it a better teaching resource, and b) individualizes it for a particular group of foreign language learners. Normally this process takes place gradually as the teacher becomes more familiar with the book since the dimensions of the text which need adaptation may not be apparent until the book is tried out in the classroom.

It is therefore virtually impossible for a given coursebook to be used without some form of adaptation. Adapting the coursebook is almost inevitable in the English classroom because a coursebook is not designed and written with a particular classroom of students in mind, and as a result, it may contain materials and tasks that the teacher feels are not suitable for his/her teaching situation. As a result, teachers will almost certainly need to adapt the coursebook, after taking into account: a) the specific needs and experiences of their students, b) the general context in which the coursebook will be used, and c) material constraints (e.g. they may not be able to choose expensive coursebooks). This adaptation may take a variety of forms. For example, teachers may choose the following types of adaptations to the coursebook they use:

1. Modification of the content of the coursebook.

The content may need to be modified because it does not suit the target learners, perhaps because of factors related to the learners' age, linguistic level, infrastructure restrictions of the school or/and classroom, or even cultural background.

2. Addition or deletion of the content of the coursebook.

The book may contain too much or too little. It is not unlikely that parts of units throughout the book should be omitted. For example a coursebook may focus primarily on listening and speaking skills and hence writing activities in the book will have to be added.

3. Reorganization of the content of the coursebook.

Teachers may decide to reorganize the book, and arrange the units in what they believe is a more appropriate order.

4. Dealing with important omissions of the coursebook.

The text may omit items that the teacher feels are important. For example a teacher may add vocabulary activities or grammar activities to a unit.

5. Modification and alteration of language tasks and activities.

Tasks, Exercises and activities may need to be changed to give them a different content and/or focus. For example a listening activity that focuses only on listening for information can adapted so that students listen a second or third time for a different purpose.

Gabrielatos (2000) argues that the adaptation of the coursebook can take the following forms: a) teachers may omit materials and tasks included in a coursebook, b) teachers may re-order/combine materials and tasks included in a coursebook, c) teachers may replace materials and tasks included in a coursebook, and d) teachers may add materials and tasks. For instance, he argues that teachers may choose to omit or modify materials and/or tasks for the following reasons:

a) Learners are already familiar with a language point, or are already competent in a skill.

b) There are too many tasks on a specific area.

c) The item/area concerned is not a priority.

d) The item/task is not well designed.

e) The item/task is not well-suited for its aim.

f) The topic is not appropriate for the learners. 
g) Texts are of inappropriate length (e.g. too long)

h) Materials are inappropriate for the aim they were designed to fulfil.

i) Materials are inappropriate for the learners' age, needs or experience.

j) Materials are unclear, confusing, or misleading.

k) Tasks are not well designed.

\section{A CASE STUDY}

The following case study is intended to illustrate a very common phenomenon in many English language classes in Greek state secondary schools. The vast student diversity in terms of language performance and knowledge presents many difficulties for the English teachers, who find it hard to work with the coursebook they use.

Mrs Andreou, a junior state high school English teacher is very concerned about the coursebook she uses. More specifically, the overall classroom level is low intermediate, so she has chosen an English coursebook of that level. However, there are marked differences between the students as far as their proficiency level and foreign language performance are concerned. First, some students, who receive private tuition have very high performance. However, she feels that the private supplementary tutoring has also negative effects on her teaching situation, because, as it has been noted in the relevant literature, it exacerbates diversity in the classroom, upsets the sequence of learning, and distorts the curriculum. In addition, all these students' parents knew English, so they could help them with assignments. For example, these students already know the materials taught in the classroom, and the coursebook as well as the language activities and tasks are "easy" for them. They complete assignments, tasks and activities in a very short period of time, and usually disrupt their fellow students who need more time to finish. They also lack motivation, because they believe that the teaching of the English language at school has very little, if anything, to offer them. By contrast, for the majority of students, the coursebook and the teaching materials represent a challenge, and they can usually complete assignments if they apply reasonable effort. The level of the coursebook corresponds to their language level, and they find the materials and the language tasks interesting and worth studying. However, their motivation is hampered by the fact that some of their fellow students' language level is substantially above the level of the coursebook and the teaching materials. Finally, a significant minority of students finds it very hard to keep up with the rest of the classroom. Their knowledge of the English language is well below the level of the coursebook (e.g. in terms of vocabulary, reading and speaking skills). None of these students' parents or older siblings knew English, so they could receive any help at home. As a result, they remain withdrawn most of the time during classes, and suffer from communication apprehension, because they are afraid that they will make to many mistakes when they speak.

On the basis of the literature presented in this chapter, the following may prove to be helpful: The three students may be provided with supplementary material and individualized tasks, while some coursebook tasks can be adjusted to their ability level. Students' parents should be informed that supplementary material aimed at helping the students, and is not a form of punishment. Engaging parents in their children's progress is a characteristic of successful teachers (Brophy, 2004). Personalizing the curriculum will also entail creating specific short and long term goals for these students, which are clear, challenging, but achievable with reasonable effort.

\section{PRactical Suggestions For EFFeCtive CCOURSEBook SElection}

Despite the fact that there are many important features of coursebooks that need to be taken into consideration when selecting a coursebook, the following criteria and principles can be used to help teachers with the often daunting task of selecting a coursebook.

a) Is task design appropriate for the aims and goals of the syllabus?

b) Do students find the tasks and texts interesting and relevant for them?

c) Is the language in the tasks relevant?

d) Is there variety in the types of tasks?

e) Are the tasks authentic, simulate real-life situations, or are they too contrived?

f) Are the objectives clearly stated for each task, so students know why they engage in a given task?

g) Are tasks and texts culturally suitable for the students?

h) Moreover, the following should be considered (Ornestein, 1995, p. 200-201):

i) The coursebook should be in line and support the teaching objectives, the teaching situation.

j) The materials in the coursebook are well organised.

k) There is a match between the difficulty level of the coursebook and students' linguistic ability.

1) The coursebook is well designed. The coursebook should be attractive with pleasant and clear illustrations, the print should be readable, with adequate margins, legible typeface, and comfortable type size.

m) The instructional design of individual tasks and of task sequences should be carefully planned.

n) The number of different materials should be limited so as not to overload or confuse students.

o) Artwork in the materials must be consistent with the text.

p) Cute, nonfunctional, space- and time-consuming materials should be avoided. 
q) When appropriate, materials should be accompanied by brief explanations of purpose for both teachers and students.

In addition, an effective coursebook should contain authentic texts, which provide students with motivation and increase engagement. The concept of authenticity refers to "actually attested language produced by native speakers for a normal communicative purpose" (Widdowson 1983, p. 30). Authentic texts are "created to fulfil some social purpose in the language community in which it was produced (Little, Devitt, and Singleton, 1988, 27). Authentic materials are important, because they are more meaningful to students, challenge their cognitive abilities, engage them personally, and increase interest and intrinsic motivation. As regards the characters in the stories in coursebooks (whether they are fictitious, or real), they shouldn't be "two dimensional and static personae who leave little for individual interpretation or imagination" (Illes, 2009, p. 6).

Apart from the issue of authenticity, coursebooks should be designed so that they provide opportunities for students to cooperate with others, engaging in project work, which can lead to increased social, cooperative skills, and group cohesiveness (Fragoulis and Tsiplakides, 2009). In addition, coursebooks should help students to develop their selfconfidence. For example, effective and well written coursebooks help to build up students' confidence by providing tasks or activities that students can cope with provided they apply reasonable effort. Coursebooks should also meet students' needs. What is covered in the textbooks should be relevant and useful to what the students need to learn and what they want to learn.

Of course, English teachers should bear in mind that an effective coursebook evaluation is not limited to assessing only the coursebook, since it is usually part of a whole package. Most publishers offer English coursebooks which are accompanied by:

a. Teacher's Book (with suggestions, lesson plans, teaching ideas, etc.)

b. Workbook

c. Activity Book

d. Companion

e. CD with the listening texts

f. Tests

g. DVD

h. CALL materials

i. Internet support

\section{CONCLUSION}

In the above discussion we have attempted to provide a synthesis of theory and practice. The overall aim of the article is to provide English teachers not only with a theoretical framework for the evaluation of coursebooks, but also with a set of practical suggestions. It has to be noted, however, that the strategies and suggestions suggested can be adapted and used by teachers in various teaching situations after taking into consideration their own teaching context.

\section{REFERENCES}

[1] Brophy, J. (2004). Motivating Students to Learn. New Jersey: Lawrence Erlbaum Associates.

[2] Carrell, D., \& Korwitz, J. (1994). Using Concordancing Techniques to Study Gender Stereotyping in ELT Textbooks. In J. Sunderland (ed.) Exploring Gender: Questions and Implications for English Language Education. Prentice Hall International.

[3] Chambers, F. (1997). Seeking consensus in coursebook evaluation, ELT Journal, 51, 29-35.

[4] Cunningsworth, A. (1984). Evaluating and Selecting EFL Teaching Materials. London: Heinemann.

[5] Cunningsworth, A. (1995). Choosing your Coursebook. Oxford: Macmillan Heinemann ELT.

[6] Ellis, R. (1997). The empirical evaluation of language teaching materials. ELT Journal, 51(1), 36-42.

[7] Fragoulis, I., \& Tsiplakides, I. (2009). Project-Based Learning in the Teaching of English as a Foreign Language in Greek primary Schools: From Theory to Practice. English Language Teaching, 2(3), 113-119.

[8] Gabrielatos, C. (2000). The coursebook as a flexible tool. Issues in ELT: Persistent Problems, Practical Solutions. TESOL Greece Special Event, Hellenic American Union, Greece, 22 October 2000.

[9] Harmer, J. (1991). The Practice of English Language Teaching: London. Longman.

[10] Haycroft, J. (1998). An Introduction To English Language Teaching. London: Longman.

[11] Hutchinson, T., \& Torres, E. (1994). The Textbooks as Agent of Change. ELT Journal 48(4), 315-328.

[12] Illes, E. (2009). What makes a coursebook series stand the test of time? ELT Journal, 63(2), 145-153.

[13] Little, D., Devitt, S., \& Singleton, D. (1988). Authentic Texts in Foreign Language Teaching: Theory and Practice. Dublin: Authentik.

[14] McDonough, J., \& Shaw, C. (1993). Materials and Methods in ELT. Oxford: Blackwell.

[15] O'Neill, R. (1982). Why Use Textbooks?. ELT Journal, 36 (2), 104-111.

[16] Ornstein, A. C. (1995). Strategies for effective teaching (2nd ed.). Madison, WI: Brown \& Benchmark.

[17] Renner, C. (1997). Women are Busy, Tall, and Beautiful: Looking at Sexism in EFL Materials. Annual Meeting of the Teachers of English to Speakers of Other Languages. Orlando, March 11-15.

[18] Richards J. C. (1993). Beyond the text book: the role of commercial materials in language teaching, RELC Journal 24 (1), 1-14.

[19] Richards, J. C., Tung, P., \& Ng, P.(1991). The Culture of the English Language Teacher. City Polytechnic of Hong Kong, Department of English. Research Report No. 6. 
[20] Sheldon, L. E. (1988). Evaluating ELT textbooks and materials. ELT Journal 42(4), 237-246.

[21] Skehan, P. (1998). A Cognitive Approach to Language Learning. Oxford: Oxford University Press.

[22] Skierso, A. (1991). Textbook selection and evaluation, in M. Celce-Murcia (Ed.) Teaching English as a second foreign language. Boston: Heinle and Heinle Publishers.

[23] Ur, P. (1991). A course in language teaching: Practice and theory. Cambridge: Cambridge University Press.

[24] Widdowson, H. G. (1983). Learning Purpose and Language Use. Oxford: Oxford University Press.

Iakovos Tsiplakides holds a B.A. in English Language and Literature from the Aristotle University of Thessaloniki, Greece, and a Master's Degree from the Greek Open University.

$\mathrm{He}$ is currently working as an English teacher in Greek state secondary schools. He has been engaged in the teaching of English as a foreign language for more than fifteen years. 